\title{
Morphological and phenological shifts in the Plantago lanceolata L. species as linked to climate change over the past 100 years
}

\author{
Svitlana Prokhorova* \& Maksym Netsvetov
}

Key words: climate change, Plantago lanceolata, herbarium, morphology, phenology, Kyiv region.

Ključne besede: podnebne spremembe, Plantago lanceolata, herbarij, morfologija, fenologija, Kijev.
Received: 16. 1. 2020

Revision received: 8. 4. 2020

Accepted: 8. 4. 2020

\begin{abstract}
Herbarium collections have proven to be irreplaceable information base in recent studies directed towards revealing shifts in plants phenology and morphology caused by climate change. We examined eight parameters of morphological traits in the perennial herb species Plantago lanceolata $\mathrm{L}$. collected in the wild between 1905 and 2019 and stored at the KW-herbarium (Kyiv, Ukraine) to find out if there were changes in plants' organ sizes during the last 114 years. For this period, we also calculated 13 climatic parameters obtained from meteorological records from the State archive that gave us the opportunity to check if there are any relations between the climate change in Kyiv region and shifts in morphological parameters of plants. Our results have shown Plantago lanceolata leaf blades, petioles and spikes had become significantly longer with time, increasing $3.0 \mathrm{~cm}$, $2.1 \mathrm{~cm}$ and $0.6 \mathrm{~cm}$ respectively. The Co-inertia analysis revealed that $34 \%$ of the morphological changes was attributed to climate change. The analysis also demonstrated that leaf length correlated more with raised temperatures when plants were in flower, while spike length depended on the temperatures during bud development. Received knowledge can be used to reveal rapid evolutionary processes of the Plantago species and predicting their further course for the construction of historical climate models based on the leaves traits.
\end{abstract}

\section{Izvleček}

Herbarijske zbirke so se v raziskavah sprememb fenologije in morfologije rastlin zaradi podnebnih sprememb pokazale kot nenadomestljiv vir informacij. Preučili smo osem dejavnikov morfoloških znakov trajnice Plantago lanceolata L., nabrane v naravi med leti 1905 in 2019 in shranjene v herbariju KW (Kijev, Ukrajina), da bi ugotovili, ali se je velikost rastlinskih organov v zadnjih 114 letih spremenila. Za to obdobje smo izračunali tudi 13 klimatskih dejavnikov iz meteoroloških podatkov državnega arhiva, ki nam omogočajo ugotavljanje odnosov med podnebnimi spremembami na območju Kijeva in spremembami morfoloških parametrov. Rezultati so pokazali, da so listne ploskve, peclji in cvetni peclji (spike) značilno daljši (za $3,0 \mathrm{~cm}, 2,1 \mathrm{~cm}$ in $0,6 \mathrm{~cm}$ ). Z analizo Co-inertia smo odkrili, da je 34\% morfoloških sprememb posledica podnebnih sprememb. Analize so tudi pokazale, da je dolžina lista v korelaciji s povišano temperaturo, ko so rastline v cvetu, medtem ko je dolžina cvetnih pecljev odvisna od temperature med razvojem popkov. Rezultati so uporabni pri odkrivanju hitrih evolucijskih procesov vrste Plantago lanceolata ter za napovedovanje razvoja in vzpostavljanju zgodovinskih klimatskih modelov na podlagi listnih znakov.

\footnotetext{
* Institute for Evolutionary Ecology of the National Academy of Sciences of Ukraine, 37 Lebedeva str., 03143, Kyiv, Ukraine.

E-mail: s.boyko.prokh@gmail.com; disfleur76@live.fr
} 


\section{Introduction}

Rising air temperatures cause shifts in plant phenology globally (Menzel 2006, Sykes 2009, Diskin et al. 2012, Wolkovich et al. 2012, Oberbauer et al. 2015) while also having an impact on the range and distribution of species including the composition and dynamics of plant communities (Ackerly et al. 2002, Walther et al. 2002, Harrison et al. 2015). Climate change impacts not only phenological traits but also other key elements of plants' fitness (Chuine 2010) reflected on a morphological scale by variations in organ size and quantities (Anderson 2016).

Investigation has, on many occasions, demonstrated that shifts in morphological variation in living organisms can be attributed to global climate change (Monty et al. 2013, Gratani 2014, Parmesan \& Hanley 2015). Alterations in the varied structural parameters of plant leaves are regularly used in similar studies due to the high sensitivity of leaves to environmental factors (Harrison et al. 2015, Baruch et al. 2016). It has been shown that leaves in colder climates are typically more toothed and more highly dissected (Royer et al. 2009). Leaves in wet climates are larger in size and have fewer, smaller teeth (Peppe et al. 2011). In the species hop bush (Dodonaea viscosa subsp. angustissima) it has been shown that climate warming can cause change in leaf sizes precisely in relation to their decreased width. The warmer the climate, the narrower were the leaves of this species (Guerin \& Lowe 2013). Other morphological traits have been used in similar studies (McAllister et al. 2018).

To expand studies of the mechanisms of plant responses to climate changes to incorporate greater time scales scientists often use herbarium specimens (Primack et al. 2004, Lavoie \& Lachance 2006, Gallagher et al. 2009, Robbirt et al. 2011, Corney et al. 2012, Lavoie 2013, Reyer et al. 2013, Mohandass et al. 2015, Willis et al. 2017, Jones \& Daehler 2018). The data saved in the herbaria of high value and dried specimens yield important correlation with regard to different aspects of observed climate change globally (Lang et al. 2019). Although the National Herbarium of Ukraine (KW) includes more than 2 million specimens, not alone from Ukraine but from other worldwide regions including well documented historical collections of French, Russian and Ukrainian botanists since the $18^{\text {th }}$ century (Shiyan 2011), the application of KW-herbarium data was limited primarily by floristic, taxonomic (Koval et al. 2018) and palynological (Bezusko et al. 2018) research up to now. Regarding the opportunities presented by the specimens and their labels, the herbarium KW data can undoubtedly be used in the studies of plant responses to climate change.
Ukraine as well as other countries of Eastern Europe has felt the effects caused by global climate change (Climate 2012). The Ukrainian climate has become milder over the last 100 years as mean annual temperatures (MAT) have increased and the amplitude of its cycles have decreased, i.e. winters have become warmer. Although increasing temperatures in Ukraine are not so dramatic in comparison to global warming figures and air temperatures have increased by only $0.6 \pm 0.2^{\circ} \mathrm{C}$ (Boychenko et al. 2016), we believe that even this small rise has had an effect on life cycles along with the internal and external structure of various plant species. In different Ukrainian regions climate changes have been dissimilar and have demonstrated correlation with regional topography, urbanization and other natural and/or anthropogenic factors. In Kyiv MAT values rose by $1.3{ }^{\circ} \mathrm{C}$ from 1878 to 2015 years. The annual amount of precipitation also increased by $38 \mathrm{~mm}$ or $6 \%$ during this period. Also the month of occurrence of the maximal precipitation value has shifted from July to June (Netsvetov et al. 2019).

The widespread growth of plantain species makes this plant a popular choice for botanical research. The sensitivity of plants of the Plantago genus to air and soil warming has appeared in many scientific publications, e.g. Donders et al. (2014) have established that warm springs and summers in previous years have resulted in an increase of pollen production in various members of the Plantago genus. Experiments have determined that the duration of the reproductive stages of Plantago virginica has significantly shortened, by as much as 5 days under warmer conditions as compared to controlled measurements (Sherry et al. 2007). Warmer soil temperature has caused shifts of the peak of flowering to the earlier date for Plantago erecta (Wolf et al. 2017) and significant shoot biomass growth by $45 \%$ for Plantago lanceolata (Thakur et al. 2014). Other investigations and experiments have shown changes in various leaf parameters in Plantago lanceolata due to climate and environmental changes (Prokhorova 2015).

We have hypothesized that 100 years of climatic changes in the Kyiv region have led to changes in the morphology and phenology of the Plantago lanceolata species. As the air temperature and amount of precipitation have risen we assumed that: 1) plants leaves and inflorescences may become bigger than before; 2) plants may start bloom and bear fruit earlier than in preceding years. To prove these hypotheses we have compared selected morphological parameters and information about phenological phases of the P. lanceolata plants taken from the herbarium (KW) and collected in the field with climatic data from the Central Geophysical Observatory (CGO). The period covered was from 1905 to 2019 (114 years). 


\section{Materials and Methods}

\section{Data collection}

We used 24 herbarium specimens (from the National Herbarium of Ukraine, KW) and 12 field-collected samples for our investigations (Table 4). We photographed dried plants and then measured morphological parameters of the plants to the nearest $0.01 \mathrm{~mm}$ resolution with AxioVision 4.7 software (Carl Zeiss). For each plant, parameters of the biggest leaf and the longest stem with the inflorescence were measured. Ratios between leaf length and width along with leaf area and petiole length were calculated.

Abbreviations of the measured variables, both morphological and climatic, for every sample point are given in the table 1 .

Table 1: Studied morphological and meteorological parameters and their abbreviations.

Tabela 1: Preučevani morfološki in meteorološki dejavniki in okrajšave.

\section{Morphological parameters}

Leaf length (with petiole), $\mathrm{cm}$

Leaf width (at the widest point), $\mathrm{cm}$

Inflorescence (flower-bearing spike) length, $\mathrm{cm}$

Length of the stem with the inflorescence, $\mathrm{cm}$

Leaf length to width ratio (L/W)

Leaf area, $\mathrm{cm}^{2}$

Leaf petiole length, $\mathrm{cm}$

Leaf area to leaf petiole length ratio (S/LP) Slp

Meteorological parameters

Air temperature in the month when the plants were $\quad \mathrm{Tm}$ collected

Humidity in the month when the plants were collected $\mathrm{Hm}$ Precipitation in the month when the plants were Pm collected

Mean annual air temperature $\quad$ Tan

Mean annual humidity $\quad$ Han

Sum of annual precipitation $\quad$ Pan

Spring air temperature (average for March, April, May) Tsp

Spring humidity Hsp

Sum of spring precipitation $\quad$ Psp

Mean annual air temperature for the year preceding of Tan-1 the year of collection

Sum of annual precipitation for previous year

Mean air temperature for the growing season Pan-1

(Tan-1 + T from January till the month of collection in the year of collection)

Sum of precipitation for the growing season

\section{Studied area}

The study area was the Kyiv region located in north-central Ukraine. The administrative center of the region is the city of Kyiv, with latitude $50.27^{\circ}$ and longitude $30.32^{\circ}$. The climate is moderately continental, with mild winters and warm summers. The medium temperature of January in the north of the region is $-6^{\circ} \mathrm{C}$, while being $-5^{\circ} \mathrm{C}$ on the southwest - and in July $+17^{\circ} \mathrm{C}$ and $+19^{\circ} \mathrm{C}$ also in respect to the north and south-west. The annual amount of precipitation is $600 \mathrm{~mm}$ in the north of the region and $500 \mathrm{~mm}$ in the south. According to the Köppen climate classification, Kyiv region has the Dfb climate type indicating acontinental climate without a dry season and with warm summers.

In our study we divided the 114-years time series on 2 sub-periods: $1^{\text {st }}$ - from 1905 to 1951 and $2^{\text {nd }}-$ from 1983 to 2019, in which studied plants were sampled.

The climate variables used in the study were all obtained directly from the monthly meteorological records taken from the Central Geophysical Observatory, Kyiv, Ukraine, for the year of sampling and the year before. Data was from 4 meteorological stations closest to sampling sites (exact locations and correspondence to sample points are given in the Table 4) (Figure 1).

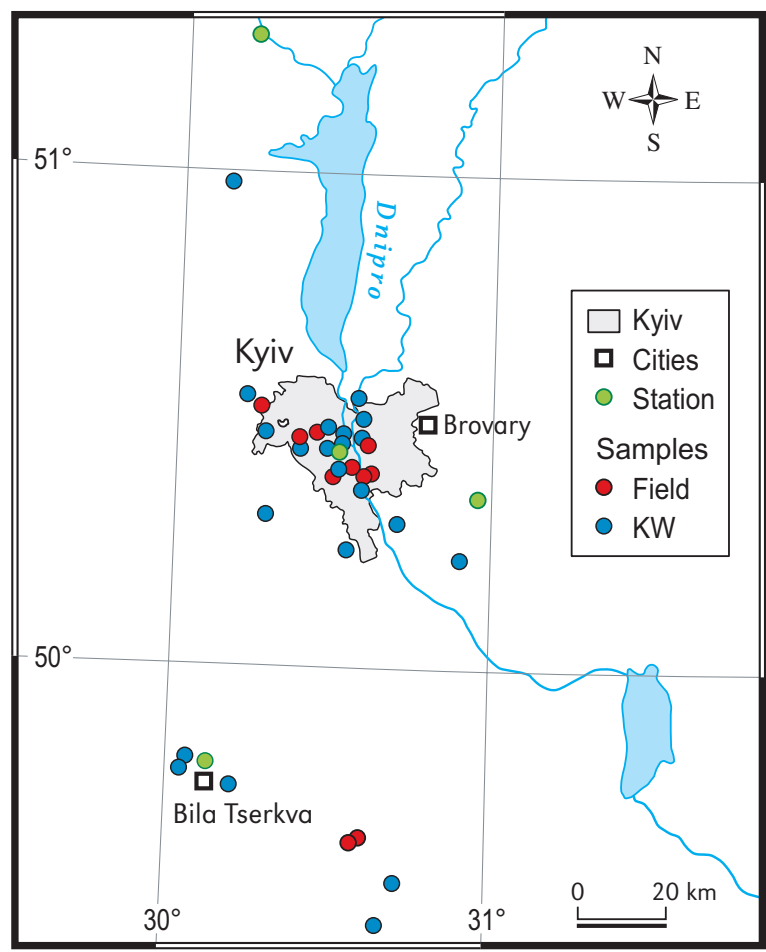

Figure 1: Custom-made map of the Kyiv region with the sampling sites and meteorological stations (created in QGIS application with Natural Earth data package).

Slika 1: Zemljevid območja Kijeva z mesti vzorčenja in meteorološkimi postajami (narejeno s programom QGIS in paketom Natural Earth). 


\section{Studied species: morphology and phenology}

Plantago lanceolata $\mathrm{L}$. is a polymorphic plant species with almost cosmopolitan distribution, native to Eurasia. Botanical description differs for different countries. The following morphological description of the species is generally accepted for Ukrainian territory: leaf length varies from 10.0 to $20.0 \mathrm{~cm}$, leaf width - from 1.0 to $4.0 \mathrm{~cm}$, the length of the leaf petioles more or less equal to the leaf length. The range of the inflorescence length is $0.5-6.5 \mathrm{~cm}$ and the length of the stem with the inflorescence $-8.0-70.0 \mathrm{~cm}$ (Flora 1961, Shipunov 1998).

Herbarium specimens of the typical Plantago lanceolata described by Linnaeus stored in Clifford's herbarium at the British Natural History Museum (Jarvis 2016). Plants described first in Linnaeus's "Species Plantarum" in 1753. They were cultivated material from the garden of G. Clifford III in Hartekamp Garden in Holland. Their average measured parameters are the next: spike length $-2.36 \mathrm{~cm}$, scape length with spike $-35.18 \mathrm{~cm}$, leaf width $-2.69 \mathrm{~cm}$, leaf length (with petiole) $25.32 \mathrm{~cm}$, petiole length $-9.77 \mathrm{~cm}$.

Plantago lanceolata is a short-lived perennial herb, which can flower from early spring until late autumn. Seeds usually germinate in autumn and overwinter in green rosettes. In spring plants produce long scapes from leaf axils with flower-bearing spikes (inflorescences) on the top.

$P$. lanceolata is a gynodioecious species, i.e. the flowers may be pistillate, staminate or hermaphroditic. Each flower has long well visible stamens or pistils (or both) outstanding from the corolla. Flowers open sequentially upwards from the base to the tip of the spike (Lacey \& Herr 2005).

The phenological stages based on the spike's state and appearance were determined as (based on the Lacey et al. (2003), Gonzalez-Parrado et al. (2015), Kara et al.(2018) works with the changes adapted to our study with herbarium specimens usage):

$\mathrm{FL}$ - a period of flowering (flowers opened, stamens or pistils are clearly visible). This period lasts on average 4 weeks in the Kyiv region. We divided it into three subperiods, each of which lasts almost 8 days, depending on the percentage of opened flowers:

FL1 - the spikes have a cone form, one third of the flowers starting from the base are opened;

FL2 - the spikes become more cylindrical, two thirds of the flowers are opened;

FL3 - the spikes have a cylindrical form, all flowers from the base to the tip are opened.

Fle - the end of flowering (more compact and dense in- florescences, cylindrically shaped, brown, the flowers without the stamens),

$\mathrm{Fr}-\mathrm{a}$ period of fruiting (the seeds are generated and dispersed from the capsules) (Figure 2).

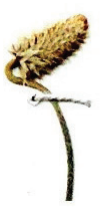

A

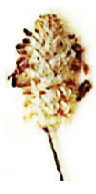

E

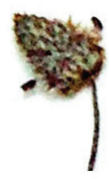

B

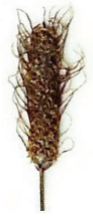

F

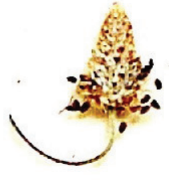

C

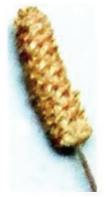

G

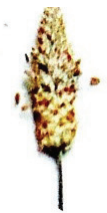

$\mathrm{D}$

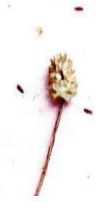

$\mathrm{H}$
Figure 2: Phenological stages defined from the herbarium specimens: A-preflowering, B, C-the beginning of the flowering (FL1-stage), D - the half flowering spike (FL2-stage), E, F - full flowering (FL3-stage, E-staminate inflorescences, F - pistillate inflorescence), $\mathrm{G}$ - the end of the flowering, $\mathrm{H}$ - fruiting.

Slika 2: Fenološki stadiji na osnovi herbarijskih primerkov: A - pred cvetenjem, B, C - začetek cvetenja (FL1-stadij), D - pol cvetoč (FL2stadij), E, F - polno cvetenje (FL3-stadij, E-socvetje z moškimi cvetovi, F -socvetje z ženskimi cvetovi), G - konec cvetenja, H - plod.

The preflowering phase is considered as the period from spike's developing until the flowers open. This phase starts near the $13^{\text {th }}-15^{\text {th }}$ week from the year beginning and lasts 1-2 weeks. In our analyses we excluded specimens at the preflowering stage to avoid errors in the measurement of plants spikes and leaves as there are evidences of wider leaves at the beginning of the plants' growing season (Van Groenenoael et al. 1986, Shipunov 1998). Samples at the fruiting stage were also excluded regarding to their insufficient amount for the analysis (only one sample for each period).

Flowering stage (from the first flowers opening until the end of flowering inclusively) can lasts from (1)3 to (5)7 weeks in average. Duration of fruiting is $2-3$ weeks. The duration of flowering and fruiting stages varies greatly depending on the plant characteristics and ambient conditions such as temperature, water and resource availability (Lacey \& Herr 2005).

To reduce flowering sub-phases from the herbaria to the approximate dates of the plants coming into flower, we subtracted 20 days from the FL3-stage date, 12 days from the FL2-stage date, 4 days from the FL1-stage date and 24 days from the Fle-stage. 


\section{Data analysis}

The Pearson correlation coefficient $(\mathrm{r})$ was calculated for the plants traits and for the climate variables. To obtain an integrated response of morphological traits to multiple climate variables, we provided two separate principal component analyses (PCA) that then were used in coinertia analysis (PCA-PCA COIA) to measure the concordance between two data sets (Dray et al. 2003).

We used the RV-coefficient to assess the strength of the morphology-to-climate relationship and performed the permutation test with $\mathrm{n}=999$ to check the RV-coefficient significance. Both PCA and COIA were calculated in R using ade 4 package and custom scripts.

\section{Results}

\section{Correlations between parameters}

The mean annual air humidity correlated negatively with the mean annual temperature and positively with the annual sum of precipitation. The air temperature in spring also correlated with the spring air humidity negatively. The air temperature in the month of sampling correlated positively with the sum of precipitation in the month of sampling (Appendix, Table 5).

Studied morphological parameters of ribwort plantain showed a high level of phenotypic integration, as strong positive correlations were observed between the most of the measured traits. High correlations were observed between the leaf length and width, the leaf length and the leaf area, the leaf blade and the petiole length, and also other leaf traits (Appendix, Table 6). The spike length and the scape length interrelated with each other and also with the leaf area and the leaf petiole length.

\section{Temporal changes}

Statistical analyses have shown significant differences between periods in humidity and precipitation amount in the month of sampling (Table 2) and also annual air temperature and annual amount of precipitation for the year preceding sampling. Air temperature had risen by $2{ }^{\circ} \mathrm{C}$ and the amount of precipitation - by $166.84 \mathrm{~mm}$ for the stud- ied region. Annual humidity in the year of sampling had decreased on $3 \%$ and average spring humidity - by $6 \%$.

Difference in air temperatures for two periods by month has been significant only for the winter months and April (increased in the second period). Precipitation amount has significantly decreased in the second period only in November (Figure 3).
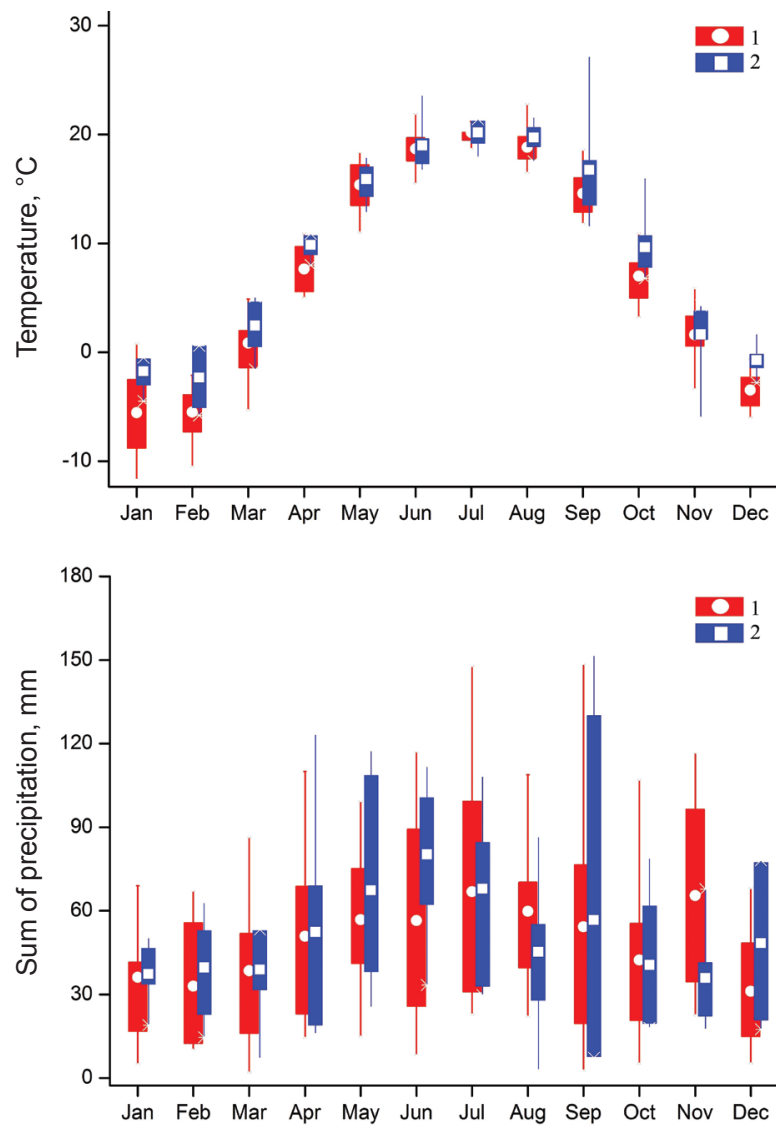

Figure 3: Comparative climatograms for Kyiv region for two periods: 1 - 1905-1951;2 -1983-2019. In the boxplots the lower and upper hinges indicate the $25^{\text {th }}$ and $75^{\text {th }}$ percentiles, the white squares and the circles inside the boxes denote the median values, the whiskers extend from the hinges to the largest and smallest values within the 1.5 interquartile range.

Slika 3: Primerjalni klimagrami za območje Kijeva za dve obdobji: 1 - 1905-1951; 2 -1983-2019. V grafikonu kvantilov spodnji in zgornji rob škatel predstavljata 25. in 75. percentil, beli kvadrati in krogi znotraj škatel mediane, ročaji pa največjo in najmanjšo vrednost znotraj 1,5 kvartila.

Table 2: Comparison of studied meteorological parameters for two periods.

Tabela 2: Primerjava preučevanih meteoroloških dejavnikov med dvema obdobjema.

\begin{tabular}{|c|c|c|c|c|c|c|c|c|c|c|c|c|c|}
\hline & $\begin{array}{l}\mathrm{Tm} \\
{ }^{\circ} \mathrm{C}\end{array}$ & $\begin{array}{l}\mathrm{Hm} \\
\%\end{array}$ & $\begin{array}{l}\mathrm{Pm} \\
\mathrm{mm}\end{array}$ & $\begin{array}{l}\text { Tan } \\
{ }^{\circ} \mathrm{C}\end{array}$ & $\begin{array}{l}\text { Han } \\
\%\end{array}$ & $\begin{array}{l}\text { Pan } \\
\mathrm{mm}\end{array}$ & $\begin{array}{l}\text { Tsp } \\
{ }^{\circ} \mathrm{C}\end{array}$ & $\begin{array}{l}\text { Hsp } \\
\%\end{array}$ & $\begin{array}{l}\text { Psp } \\
\mathrm{mm}\end{array}$ & $\begin{array}{l}\text { Tan-1 } \\
{ }^{\circ} \mathrm{C}\end{array}$ & $\begin{array}{l}\text { Pan-1 } \\
\mathrm{mm}\end{array}$ & $\begin{array}{l}\text { Tss-1 } \\
{ }^{\circ} \mathrm{C}\end{array}$ & $\begin{array}{l}\text { Pss-1 } \\
\mathrm{mm}\end{array}$ \\
\hline 951 & 18.14 & 66.33 & 52.96 & 7.77 & 76.50 & 621.68 & 8.54 & 73.00 & 140.51 & 7.32 & 624.07 & 9.89 & 849.92 \\
\hline $1983-2019$ & 20.09 & $63.39^{*}$ & $72.04^{*}$ & $9.04^{* *}$ & $73.47^{* *}$ & 544.63 & 9.90 & $67.22^{* *}$ & 143.98 & $9.32^{* *}$ & $790.91^{* *}$ & $13.67^{* *}$ & $1003.92^{* *}$ \\
\hline
\end{tabular}

Note: the asterisks indicate a significant difference between two periods: ${ }^{*} \mathrm{p}<0.05,{ }^{* *} \mathrm{p}<0.01$. 
Table 3: Comparison of the morphological parameters for two periods.

Tabela 3: Primerjava morfoloških parametrov med dvema obdobjema.

\begin{tabular}{cccccccccc} 
& $\mathrm{L}$ & $\mathrm{W}$ & $\mathrm{Li}$ & $\mathrm{Lg}$ & $\mathrm{LWr}$ & $\mathrm{S}$ & $\mathrm{LP}$ & Slp \\
$1905-1951$ & $12.34 \pm 3.10$ & $1.38 \pm 0.40$ & $1.72 \pm 0.40$ & $36.69 \pm 8.60$ & $9.25 \pm 2.10$ & $8.02 \pm 3.70$ & $4.25 \pm 1.60$ & $2.03 \pm 1.10$ \\
& {$[0.25]$} & {$[0.28]$} & {$[0.24]$} & {$[0.23]$} & {$[0.22]$} & {$[0.47]$} & {$[0.37]$} & {$[0.55]$} \\
& $(7.00-20.00)$ & $(0.60-2.30)$ & $(1.00-2.60)$ & $(22.40-55.30)$ & $(5.30-13.30)$ & $(2.10-15.60)$ & $(2.00-8.10)$ & $(0.50-5.30)$ \\
$1983-2019$ & $15.49 \pm 5.60^{*}$ & $1.48 \pm 0.40$ & $2.36 \pm 0.90^{* *}$ & $38.99 \pm 10.50$ & $10.39 \pm 2.70$ & $11.28 \pm 5.80$ & $6.39 \pm 3.00^{* *}$ & $1.88 \pm 0.80$ \\
& {$[0.36]$} & {$[0.25]$} & {$[0.37]$} & {$[0.27]$} & {$[0.26]$} & {$[0.51]$} & {$[0.48]$} & {$[0.45]$} \\
& $(7.40-22.60)$ & $(0.90-2.20)$ & $(1.40-4.20)$ & $(19.00-61.30)$ & $(6.70-14.60)$ & $(2.80-22.70)$ & $(2.10-12.70)$ & $(1.00-3.70)$ \\
\hline
\end{tabular}

Note: mean \pm standard deviation [coefficient of variation] (min-max), the asterisks indicate a significant difference between two periods: ${ }^{*} \mathrm{p}<0.05,{ }^{* *} \mathrm{p}<0.01$.

Such morphological parameters as leaf length (plus $3.0 \mathrm{~cm}$ ), inflorescence length (plus $0.6 \mathrm{~cm}$ ), leaf petiole length (plus $2.1 \mathrm{~cm}$ ) have increased in the $2^{\text {nd }}$ period significantly (Table 3).

The full flowering stage in the $2^{\text {nd }}$ period displaced at the end of May (155 th day of a year) from the middle of June in the $1^{\text {st }}$ period ( $165^{\text {th }}$ day of a year). Although the linear trend showed an earlier start of flowering in the 2nd period, this shift was insignificant (Figure 4).

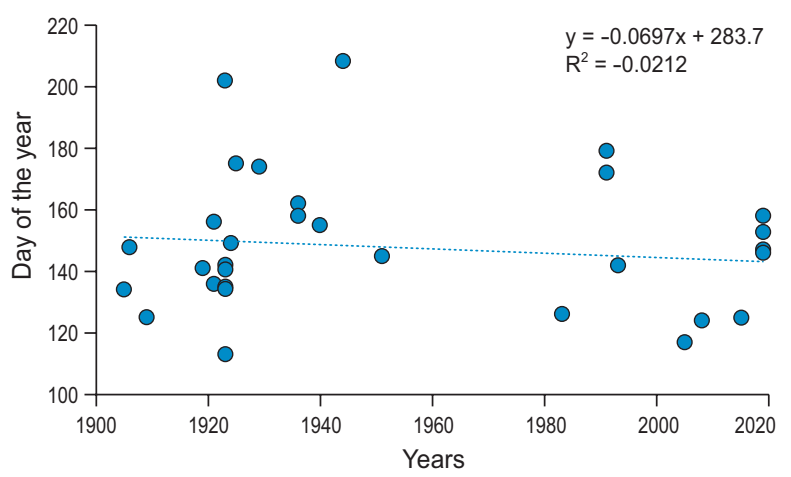

Figure 4: Two-way scatter plot showing the relationship between Plantago lanceolata $\mathrm{L}$. flowering onset dates and period of data collection.

Slika 4: Dvo-razsežnostni diagram prikazuje odnos med datumi začetka cvetenja vrste Plantago lanceolata $\mathrm{L}$. in časom nabiranja primerkov.

Figure 5: The PCA two-dimensional plot showing a separation of (A) morphological and (B) climatic data sets in two periods. Points denote individuals' scores, i.e. individuals' coordinates. As plants sampled in one year from close sites share the same climatic condition, several points overlap in the plate (B). The stars connect the individuals with the grouping means, and the ellipses indicate group inertia.

Slika 5: Dvodimenzionalni PCA diagram z ločenimi (A) morfološkimi in (B) klimatskimi podatki obeh obdobij. Točke predstavljajo posamezne rezultate, to je individualne koordinate. Rastline, vzorčene isto leto z bližnjih lokacij, imajo enake klimatske razmere, številne točke se prekrivajo na sliki B. Zvezde povezujejo posamezne točke s skupnim povprečjem, elipse predstavljajo celotno variabilnost.
The PCA-analysis displays a separation between the two periods both for morphological and for climatic data set (Figure 5). The Co-inertia analysis performed for both PCA results showed the relationships between the morphology and the climate data sets (Figure 6).
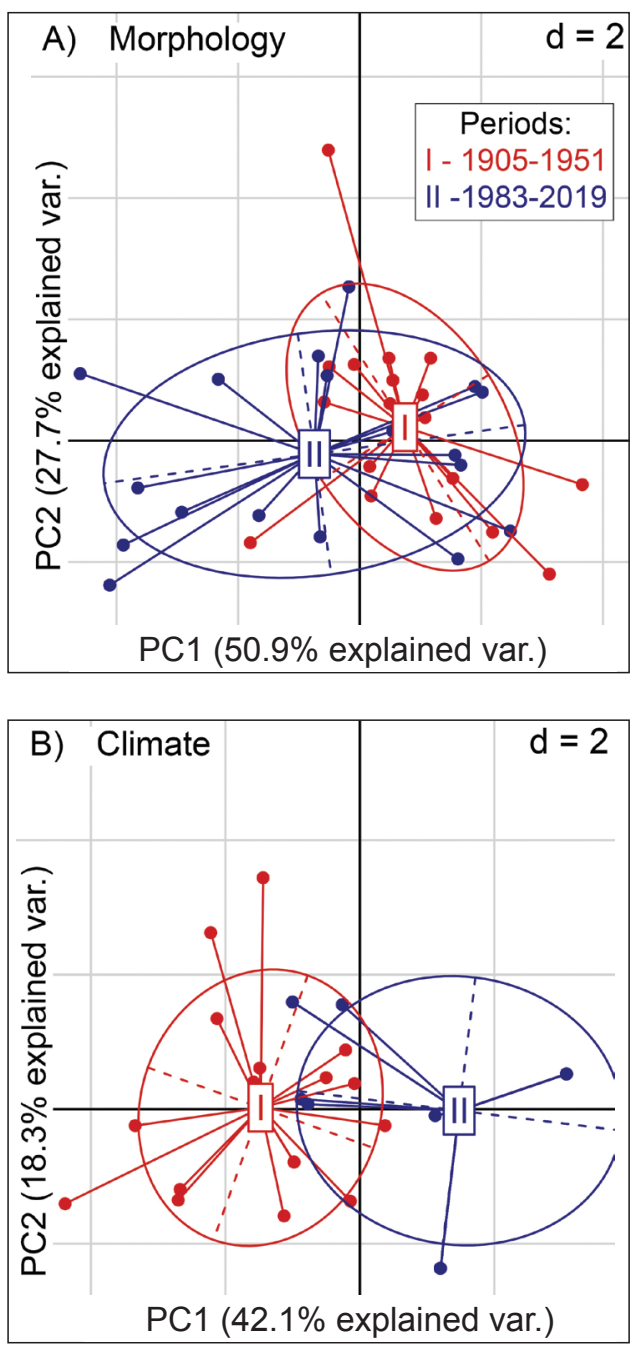

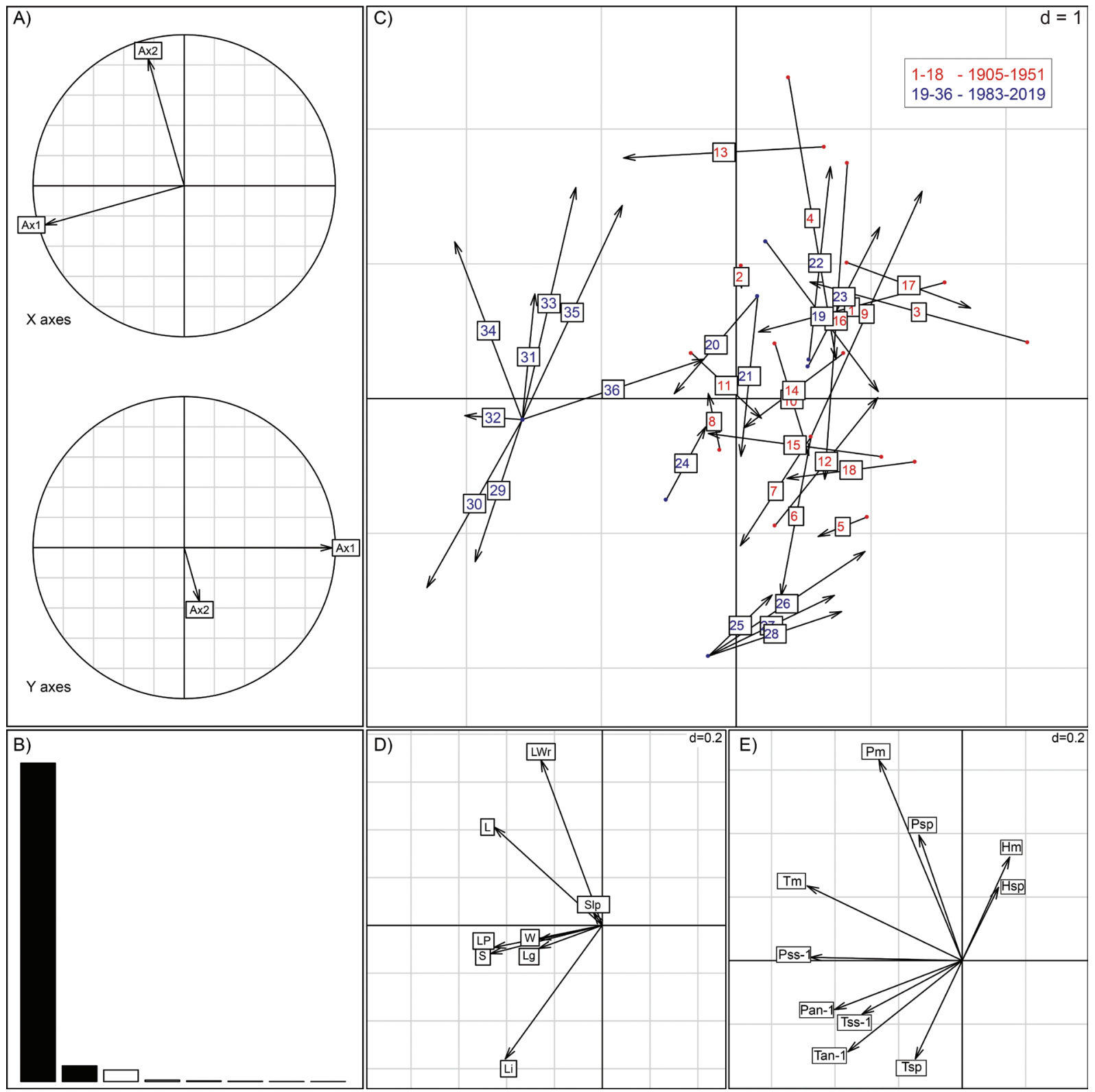

Figure 6: PCA-PCA Co-inertia analysis. (A) The projections of the PCA axes from the climate data (upper circle) and morphological data (lower circle) onto the axes of the COIA. (B) The scree plot of the eigenvalues of the COIA. (C) The scatterplot of the studied sites projection on COIA's axes; the climatic description of the sites places at the beginning of the arrow and morphological descriptions sets at the ends of the arrow; the sites, i.e. individuals, numbers are shown in rectangles. (D) The scatter plots of the coefficients of the combinations of morphological variables and (E) climate variables.

Slika 6: Analiza PCA-PCA Co-inertia. (A) Projekcije PCA osi iz klimatskih podatkov (zgornji krožci) in morfoloških podatkov na osi analize COIA. (B) Diagram lastnih vrednosti analize COIA. (C) Razsevni diagram preučevanih lokalitet, projiciranih na COIA osi; klimatski opis lokalitet na začetku puščic in morfološki opis na koncu; lokalitete oz. posamezni osebki so kot številke prikazane v pravokotnikih. (D) Razsevni diagram koeficientov kombinacij morfoloških spremenljivk in (E) klimatske spremenljivke.

The RV-coefficient, i.e. the correlation between the two data sets (morphological and climatic), was 0.34 and differed from what could be expected by chance, as the permutation test gave the simulated $\mathrm{p}$-value $<0.01$. The environmental PCA first axes were projected in the joint coordinates orienting along the first COIA's axis and the morphological PCA first axis was oriented along the second COIA's axis (Figure 6 A-B). The first two COIA's 
axes explained $>95 \%$ of the cumulative projected inertia (Figure $6 \mathrm{C}$ ). The leaf length-to-width ratio links mostly to the changes of the amount of precipitation in the month of sampling (Figure $6 \mathrm{D}-\mathrm{E}$ ) and was large in the individuals from both periods (points 13 and 33, 35 at the Figure $6 \mathrm{~B}$ ). The spike length correlated with the air temperature in the year preceding sampling, while the leaf length correlated with the air temperature in the month of sampling.

The leaf area and the leaf petiole length are correlated with the sum of precipitations of the previous year ( $\mathrm{r}$ was 0.54 and 0.51 respectively). The less variable leaf width and scape length were also related to the sum of precipitation of the previous growing season. Leaf area to leaf petiole length ratio did not vary greatly and showed no correlation with the studied climatic variables (Appendix, Table 8).

The overall structure of data sets projection on COIA axes suggested that in the first period 1905-1951 leaves and inflorescence were shorter and smaller (see Figure 6 B). In the second period, an overall morphology shifted toward the longer leaf blades, petioles and spikes particularly in 2019.

\section{Discussion}

According to available evidence there have been marked changes in climatic parameters in the Kyiv region over the past 114 years. Air temperature and precipitation amounts have increased during this period. In our study we used the parameters not for the whole 114-years period but for the particular years that are joined to the herbarium data. With regard to the data we can confirm a statistically significant rise in the amount of precipitation and the annual air temperature in the months in which plant specimens were collected (plants were collected from May to August) and in the year preceding sampling. The air humidity during the sample collecting months, in spring and for the whole year was observed to be at lower levels. The main contribution to the climate changes in the Kyiv region was made by the Dnipro river regulation (in 1964 and 1977 years). After the construction of two dams on the Dnipro river, which disrupted it's natural flow, there was a large increase in the water surface area in the Kyiv region leading to increases in both precipitation levels and temperature in the years after 1977 (Netsvetov et al. 2018).

The leaf length, the leaf petiole length and the spike length of the Plantago lanceolata plants have increased significantly from the 1 st to the $2^{\text {nd }}$ period according to our analysis by $3.0 \mathrm{~cm}, 2.1 \mathrm{~cm}$ and $0.6 \mathrm{~cm}$ correspond- ingly. The inflorescence size has become closer to those typical of Plantago plants which were described by Linnaeus. The leaves have become larger in size mostly due to the petiole length increasing, but still didn't reach the typical form size (the leaf length $15.49 \mathrm{~cm}$ vs $25.32 \mathrm{~cm}$ accordingly).

As COIA analysis has shown, 34\% of morphological changes can be attributed to the climatic parameters changes, in particular, in the increasing temperatures and precipitation levels.

Although the precipitation itself may not directly affect plants, it influences air and soil moisture levels essential to nutrient uptake in the plants. Increased precipitation leads to the better colonization of $P$. lanceolata plants by the arbuscular mycorrhizal fungi that can strongly affect plant growth (Walter et al. 2016). Increased levels water supply to plants at the reproductive stage is the key factor for the better green mass growth for Plantago lanceolata.

While the leaf size depends more on the conditions of the current year of plant sampling (reproductive stage), the spike size depends more on the conditions of the previous year (vegetative stage) and can be explained by the ontogenesis features of the species. After seed germination in the autumn, the rosette of the leaves is formed. The generative shoots start to develop in the axillary buds from the third leaf. In this stage plants overwinter and fully develop generative shoots in the spring. We can propose that the spike size is mostly determined by the ambient conditions on the stage of their forming in buds.

It is known Plantago lanceolata plants size significantly correlates with the flowering data (Lacey et al. 2003, Shefferson \& Roach 2010): larger plants flower earlier. The plants that flower earlier in turn fruit earlier too and make larger amount of seeds during the longer time than those that flower later in the season (Lacey $\&$ Herr 2000). The onset of the flowering is undoubtedly connected with the ambient temperature: the earlier it is warm in spring, the earlier P. lanceolata plants flower (Teramura et al. 1981, Valencia et al. 2016); the length of the day (Snyder 1948, Van Groenenoael 1986) and the temperature of the parental plants: the lower parental temperature is, the earlier offspring flowers in spring (Case et al. 1996, Lacey 1996).

The shift of the flowering onset to the earlier dates of a year could be an adaptive reaction of plants to avoid summer heat and competition from other species as it was proved Plantago lanceolata is not a good competitor (Van Tienderen \& Van der Toorn 1991) and grows better in monocultures or amongst less diverse vegetation (Wolf et al. 2017). Furthermore, the phenological shift could be a compensatory mechanism aimed at the reproduction (Ream et al. 2014) and pollination (Clif- 
ford 1962) efficiency improving and preventing seed loss caused by insects-predators appearing in the middle of the summer (Lacey et al. 2003).

Based on all these facts we expected a significant phenological shift in flowering and fruiting dates of Plantago plants in the second period, but our hypothesis wasn't confirmed, although a weak tendency to such displacement was observed. This can be explained by the longlasting period of plants flowering that can continue from May to October. Plants in different generative stages can occur together throughout the growing season. In 2019 only in a 10 -days period (from $16^{\text {th }}$ to $26^{\text {th }}$ of June) we managed to collect plants in all generative phases - from those that just started to flower to those that had already produced seeds.

Although in this study we didn't check if the responses at the morphological level are fixed genetically, it can possibly be done with a garden experiment similar to the Ravenscroft's et al. (2015) investigation. At the same time experimental investigations should be supported with the long-term observations that are possible using herbaria data.

The amplitude of the within-population variability in this study is also unknown but can be obtained from the field investigation in the future and used to extend the herbarium data as a model. Further broader investigations of both spatial and temporal changes can give a clearer overall answer about what other factors affect Plantago variability.

The received knowledge can not only be used for pointing out the accelerated evolutionary processes of the P. lanceolata species (Antonovics \& Primack 1982, Wolff 1987, Wolff \& Van Delden 1987, Lacey 1996, Van Hinsberg 1997), but also in paleoclimatology to help interpret paleoclimate based on the morphological traits of the fossil leaves (Peppe et al. 2018, Roth-Nebelsick \& Konrad 2019).

\section{Acknowledgements}

The authors are sincerely grateful to Matt Goggin for his invaluable help in article linguistic editing and Alice Vavrisevich for her highly-qualified translation assistance. We also thank to the staff of the National Herbarium of Ukraine and the Sectoral State Archive of Materials of Hydrometeorological Observations of the State Emergency Service of Ukraine for their assistance.

\section{References}

Ackerly, D., Knight, C., Weiss, S., Barton, K., Starmer K. 2002: Leaf size, specific leaf area and microhabitat distribution of chaparral woody plants: contrasting patterns in species level and community level analyses. Oecologia 130: 449-457. https://doi.org/10.1007/ s004420100805.

Anderson, J. T. 2016: Plant fitness in a rapidly changing world. New phytologist 210: 81-87. https://doi.org/10.1111/nph.13693.

Antonovics, J. \& Primack, R. 1982: Experimental ecological genetics in Plantago. VI. The demography of seedling transplants of $P$. lanceolata. Journal of Ecology 70: 55-75.

Baruch, Z., Christmas, M. J., Breed, M. F., Guerin, G. R., CaddyRetalic, S., McDonald, J., Jardine, D. I., Leitch, E., Gellie, N., Hill, K., McCallum, K., Lowe, A. J. 2016: Leaf trait associations with environmental variation in the wide-ranging shrub Dodonaea viscosa subsp. Angustissima (Sapindaceae). Austral Ecology. https://doi. org/10.1111/aec.12474.

Bezusko, L. G., Tsymbalyuk, Z. M., Mosyakin, S. L. 2018: Spatiotemporal differentiation and distribution patterns of the genus Plantago L. (Plantaginaceae) in the plain part of Ukraine during the Allerød-Holocene. Modern Phytomorphology 12: 95-105. https:// doi.org/10.5281/zenodo.1319359.

Boychenko, S., Voloshchuk, V., Movchan, Y., Serdjuchenko, N., Tkachenko, V., Tyshchenko, O., Savchenko, S. 2016: Features of climate change on Ukraine: scenarios, consequences for nature and agroecosystems. Proceedings of the National Aviation University 4 (69): 96-113. https://doi.org/10.18372/2306-1472.69.11061.

Case, L. A., Lacey, E. P., Hopkins, R. G. 1996: Parental effects in Plantago lanceolata L. II. Manipulation of grandparental temperature and parental flowering time. Heredity 76: 287-295.

Chuine, I. 2010: Why does phenology drive species distribution? Philosophical transactions of the Royal Society B 365: 3149-3160. doi: 10.1098/rstb.2010.0142.

Clifford, T. H. 1962: Insect pollination of Plantago lanceolata L. Nature 13 (193): 196.

Climate change in Eastern Europe. Belarus, Moldova, Ukraine. 2012: ENVSEC, Zoï environment network, 60 p.

Corney, D. P. A., Clark, J. Y., Tang, L. H., Wilkin, P. 2012: Automatic extraction of leaf characters from herbarium specimens. Taxon 61 (1): 231-244.

Diskin, E., Proctor, H., Jebb, M., Sparks, T., Donnelly, A. 2012: The phenology of Rubus fruticosus in Ireland: herbarium specimens provide evidence for the response of phenophases to temperature, with implications for climate warming. International Journal of Biometeorology 56: 1103. https://doi.org/10.1007/s00484-0120524-z.

Donders, T., Hagemans, K., Dekker, S. C., de Weger, L. A., de Klerk, P., Wagner-Cremer, F. 2014: Region-specific sensitivity of anemophilous pollen deposition to temperature and precipitation. PLoS One 9 (8): e104774. https://doi.org/10.1371/journal. pone. 0104774 .

Dray, S., Chessel, D., Thioulouse, J. 2003: Co-inertia analysis and the linking of ecological data tables. Ecology 84: 3078-3089. doi:10.1890/03-0178. 
Flora URSR: Vol. 10. 1961, Kyiv, pp. 69-90 [In Ukrainian].

Gallagher, R. V., Hughes, L., Leishman, M. R. 2009: Phenological trends among Australian alpine species: using herbarium records to identify climate-change indicators. Australian Journal of Botany 57: 1-9. doi: 10.1071/BT08051.

Gonzalez-Parrado, Z., Fernandez-Gonzalez, D., Vega-Maray, A. M., Valencia-Barrera, R. M. 2015: Relationship between flowering phenology, pollen production and atmospheric pollen concentration of Plantago lanceolata (L.). Aerobiologia. doi 10.1007/s10453-015-9377-3.

Gratani, L. 2014: Plant phenotypic plasticity in response to environmental factors. Advances in Botany 2014: 208747. http:// dx.doi.org/10.1155/2014/208747.

Guerin, G. \& Lowe, A. 2013: Leaf morphology shift: new data and analysis support climate link. Biology Letters 9: 1-3. http://dx.doi. org/10.1098/rsbl.2012.0860.

Harrison, S. Damschen, E., Fernandez-Going, B., Eskelinen, A., Copeland, S. 2015: Plant communities on infertile soils are less sensitive to climate change. Annals of Botany 116: 1017-1022. https://doi.org/10.1093/aob/mcu230.

Jarvis, C. 2016: Dataset: Clifford Herbarium. Natural History Museum Data Portal (data.nhm.ac.uk). https://doi. org/10.5519/0022031

Jones, C. A. \& Daehler, C. C. 2018: Herbarium specimens can reveal impacts of climate change on plant phenology; a review of methods and applications. PeerJ 6: e4576. doi: 10.7717/peerj.4576.

Kara, K., Ozkaya, S., Baytok, E., Guclu, B. K., Aktug, E., Erbas, S. 2018: Effect of phenological stage on nutrient composition, in vitro fermentation and gas production kinetics of Plantago lanceolata herbage. Veterinarni Medicina 63 (06): 251-260. https://doi. org/10.17221/2/2017-VETMED.

Koval, L. V., Horshkova, L. M., Kuzmenko, L. O., Mehem, O. M., Burchak, L. V., Polyakova, A. S. 2018: Sozological peculiarities of the flora of the Desna Plateau (Ukraine). Biosystems Diversity 26 (1): 37-45. doi: 10.15421/011806.

Lacey, E. P. \& Herr, D. 2000: Parental effects in Plantago lanceolata L. III. Measuring parental temperature effects in the field. Evolution 54 (4): 1207-1217. doi:10.1111/j.0014-3820.2000.tb00555.x.

Lacey, E. P. \& Herr, D. 2005: Phenotypic plasticity, parental effects, and parental care in plants? I. An examination of spike reflectance in Plantago lanceolata (Plantaginaceae). American Journal of Botany 92 (6): 920-930.

Lacey, E. P. 1996: Parental effects in Plantago lanceolata. L. I. A growth chamber experiment to examine pre-and post-zygotic temperature effects. Evolution 50 (2): 865-878.

Lacey, E. P., Roach, D. A., Herr, D., Kincaid, S., Perrott, R. 2003: Multigenerational effects of flowering and fruiting phenology in Plantago lanceolata. Ecology 84 (9): 2462-2475.

Lang, P., Willems, F. M., Scheepens, J. F., Burbano, H. A., Bossdorf, O. 2019: Using herbaria to study global environmental change. New phytologist 221: 110-122. https://doi.org/10.1111/nph.15401.

Lavoie, C. \& Lachance, D. 2006: A new herbarium-based method for reconstructing the phenology of plant species across large areas. American Journal of Botany 93 (4): 512-516. doi: 10.3732/ ajb.93.4.512.
Lavoie, C. 2013: Biological collections in an ever changing world: Herbaria as tools for biogeographical and environmental studies. Perspectives in Plant Ecology, Evolution and Systematics 15: 68-76. http://dx.doi.org/10.1016/j.ppees.2012.10.002.

McAllister, C., McKain, M. R., Li, M., Bookout. B., Kellogg, E. A. 2018: Specimen-based analysis of morphology and the environment in ecologically dominant grasses: the power of the herbarium. Philosophical Transactions Royal Society B 374: 20170403. http:// dx.doi.org/10.1098/rstb.2017.0403

Menzel, A. 2006: European phenological response to climate change matches the warming pattern. Global Change Biology 12: 1969-1976. doi: 10.1111/j.1365-2486.2006.01193.x.

Mohandass, D., Zhao, J., Xia, Y., Campbell, J., Li, Q. 2015: Increasing temperature causes flowering onset time changes of alpine ginger Roscoea in the Central Himalayas. Journal of AsiaPacific Biodiversity 8 (3): 191-198. https://doi.org/10.1016/j. japb.2015.08.003.

Monty, A., Bizoux, J.-P., Escarré, J., Mahy, G. 2013: Rapid plant invasion in distinct climates involves different sources of phenotypic variation. PLoS ONE 8(1): e55627. https://doi.org/10.1371/journal. pone. 0055627.

Netsvetov, M., Prokopuk, Y., Didukh, Y., Romenskyy, M. 2018: Climatic sensitivity of Quercus robur L. in floodplain near Kyiv under river regulation. Dendrobiology 79: 20-33. http://dx.doi. org/10.12657/denbio.079.003.

Netsvetov, M., Prokopuk, Y., Puchałka, R., Koprowski, M., Klisz, M., Romenskyy, M. 2019: River regulation causes rapid changes in relationships between floodplain oak growth and environmental variables. Frontiers in Plant Science 10 (96): 1-11. https://doi. org/10.3389/fpls.2019.00096

Oberbauer, S. F., Elmendorf, S. C., Troxler, T. G., Hollister, R. D., Rocha, A. V., Bret-Harte, M. S., Dawes, M. A., Fosaa, A. M., Henry, G. H. R., Høye, T. T., Jarrad, F. C., Jónsdóttir, I. S., Klanderud, K., Klein, J. A., Molau, U., Rixen, C., Schmidt, N. M., Shaver, G. R., Slider, R. T., Totland, Ø., Wahren, C.-H., Welker, J. M. 2015: Phenological response of tundra plants to background climate variation tested using the International Tundra Experiment. Philosophical transactions of the Royal Society B: 1-13. doi: 10.1098/rstb.2012.0481.

Parmesan, C. \& Hanley, E. 2015: Plants and climate change: complexities and surprises. Annals of Botany 116: 849-864. doi:10.1093/aob/mcv169.

Peppe, D. J., Baumgartner, A., Flynn, A., Blonder, B. 2018: Reconstructing paleoclimate and paleoecology using fossil leaves. In Vertebrate Paleobiology and Paleoanthropology: 289-317. https://doi. org/10.1007/978-3-319-94265-0_13.

Peppe, D., Royer, D. L., Cariglino, B., Oliver, S. Y., Newman, S., Leight, E., Enikolopov, E., Fernandez-Burgos, M., Herrera, F., Adams, J. M., Correa, E., Currano, E. D., Erickson, J. M., Hinojosa, L. F., Hoganson, J. W., Iglesias, A., Jaramillo, C. A., Johnson, K. R., Jordan, G. J., Kraft, N. J. B., Lovelock, E. C., Lusk, C. H., Niinemets, Ü., Peñuelas, J., Rapson, G., Wing, S. L., Wright, I. J. 2011: Sensitivity of leaf size and shape to climate: global patterns and paleoclimatic applications. New Phytologist 190 (3): 724-739. https://doi. org/10.1111/j.1469-8137.2010.03615.x.

Primack, D., Imbres, C., Primack, R. B., Miller-Rushing, A. J., Del Tredici, P. 2004: Herbarium specimens demonstrate earlier flowering in response to warming in Boston. American Journal of Botany 91: 1260-1264. doi: 10.3732/ajb.91.8.1260. 
Prokhorova, S. 2015: Variability of the Plantago lanceolata L. morphological parameters along the transect from natural to anthropogenically disturbed sites. Chornomorski Botanical Journal 11 (4): 412-421. doi:10.14255/2308-9628/15.114/1.

Ravenscroft, C., Whitlock, R., Fridley J. D. 2015: Rapid genetic divergence in response to 15 years of simulated climate change. Global Change Biology 21: 4165-4176. https://doi.org/10.1111/gcb.12966.

Ream, T. S., Woods, D. P., Schwartz, C. J., Sanabria, C. P., Mahoy, J. A., Walters, E. M., Kaeppler, H. F., Amasino, R. M. 2014: Interaction of photoperiod and vernalization determines flowering time of Brachypodium distachyon. Plant Physiology 164: 694-709. https://doi.org/10.1104/pp.113.232678.

Reyer, C., Leuzinger, S., Rammig, A., Wolf, A., Bartholomeus, R. P., Bonfante, A., de Lorenzi, F., Dury, M., Gloning, P., Jaoudé, R. A., Klein, T., Kuster, T. M., Martins, M., Niedrist, G., Riccardi, M., Wohlfahrt, G., de Angelis, P., de Dato, G., François, L., Menzel, A., Pereira, M. 2013: Review A plant's perspective of extremes: terrestrial plant responses to changing climatic variability. Global Change Biology 19: 75-89. https://doi.org/10.1111/gcb.12023.

Robbirt, K. M., Davy, A. J., Hutchings, M. J., Roberts, D. L. 2011: Validation of biological collections as a source of phenological data for use in climate change studies: a case study with the orchid Ophrys sphegodes. Journal of Ecology 99 (1): 235-241. https://doi. org/10.1111/j.1365-2745.2010.01727.x.

Roth-Nebelsick, A. \& Konrad, W. 2019: Fossil leaf traits as archives for the past - and lessons for the future? Flora 254: 59-70. https://doi. org/10.1016/j.flora.2018.08.006.

Royer, D. L., Neyerson L. A., Adams J. M. 2009: Phenotypic plasticity of leaf shape along a temperature gradient in Acer rubrum. PloS one. doi: $10.1371 /$ journal.pone. 0007653 .

Shefferson, R. P. \& Roach D. A. 2010: Longitudinal analysis of Plantago: adaptive benefits of iteroparity in a short-lived, herbaceous perennial. Ecology 91 (2): 441-447.

Sherry, R., Zhou, X., Gu, S., Arnone III, J. A., Schimel, D. S., Verburg, P. S., Wallace, L. L., Luo, Y. 2007: Divergence of reproductive phenology under climate warming. PNAS 104 (1): 198-202. https:// doi.org/10.1073/pnas.0605642104

Shipunov, A. B. 1998: Plantains (genus Plantago L. and Psyllium Mill., Plantaginaceae) of the European part of Russia and adjacent territories: PhD thesis, Moscow, 301 p. [In Ukrainian].

Shiyan, N. M. 2011: National Herbarium of Ukraine - Herbarium of the M. G. Kholodny Institute of Botany, NAS of Ukraine. Herbarium of Vascular Plants (KW). In: Shiyan, N. M. (eds.): Herbaria of Ukraine. Index Herbariorum Ucrainicum. Alterpress, Kyiv, pp.87-11.

Snyder, W. E. 1948: Mechanism of the photoperiodic response of Plantago lanceolata L., a long-day plant. American Journal of Botany 35 (8): 520-525. doi: 10.2307/2438170.

Sykes, M. 2009: Climate change impacts: Vegetation. Encyclopedia of Life Sciences. doi: 10.1002/9780470015902.a0021227.

Teramura, A. H., Antonovics J., Strain, B. R. 1981: Experimental ecological genetics in Plantago IV. Effects of temperature on growth rates and reproduction in three populations of Plantago lanceolata $\mathrm{L}$. (Plantaginaceae). American Journal of Botany: 68 (3): 425-434. doi: $10.2307 / 2442780$
Thakur, M. P., Reich, P. B., Eddy, W. C., Stefanski, A., Rich, R., Hobbie, S. E., Eisenhauer, N. 2014: Some plants like it warmer: Increased growth of three selected invasive plant species in soils with a history of experimental warming. Pedobiologia 57: 57-60. http:// dx.doi.org/10.1016/j.pedobi.2013.12.002.

Valencia, E., Mendez, M., Saavedra, N., Maestre, F. T. 2016: Plant size and leaf area influence phenological and reproductive responses to warming in semiarid Mediterranean species. Perspectives in Plant Ecology, Evolution and Systematics 21: 31-40. https://doi. org/10.1016/j.ppees.2016.05.003.

Van Groenenoael, J. M. 1986: Life history characteristics of two ecotypes of Plantago lanceolata L. Acta Botanica Neerlandica 35 (2): 71-86. https://doi.org/10.1111/j.1438-8677.1986.tb00463.x.

Van Hinsberg, A. 1997: Morphological variation in Plantago lanceolata L.: effects of light quality and growth regulators on sun and shade populations. Journal of Evolutionary Biology 10: 687-701. https://doi. org/10.1046/j.1420-9101.1997.10050687.x.

Van Tienderen, P. H. \& Van der Toorn, J. 1991: Genetic differentiation between populations of Plantago lanceolata. I. Local adaptation in three contrasting habitats. Journal of Ecology 79: 27-42. doi: $10.2307 / 2260783$.

Walter, J., Kreyling, J., Singh, B. K., Jentsch, A. 2016: Effects of extreme weather events and legume presence on mycorrhization of Plantago lanceolata and Holcus lanatus in the field. Plant Biology 18: 262-270. doi:10.1111/plb.12379.

Walther, G.-R., Post, E., Convey, P., Menzel, A., Parmesan, C., Beebee, T. J. C., Fromentin, J.-M., Hoegh-Guldberg, O., Bairlein, F. 2002: Ecological responses to recent climate change. Nature 416: 389-395. https://doi.org/10.1038/416389a.

Willis, C. G., Ellwood, E. R., Primack, R. B., Davis, C. C. , Pearson, K. D., Gallinat, A. S., Yost, J. M., Nelson, G., Mazer, S. J., Rossington, N. L., Sparks, T. H., Soltis, P. S. 2017: Old plants, new tricks: phenological research using herbarium specimens. Trends in Ecology \& Evolution 32 (7): 531-546. doi: 10.1016/j.tree.2017.03.015.

Wolf, A. A., Zavaletad, E. S., Selmants, P. C. 2017: Flowering phenology shifts in response to biodiversity loss. PNAS 114 (13): 3463-3468. https://doi.org/10.1073/pnas.1608357114.

Wolff, K. \& Van Delden, W. 1987: Genetic analysis of ecological relevant morphological variability in Plantago lanceolata L. I Population characteristics. Heredity 58: 183-192.

Wolff, K. 1987: Genetic analysis of ecological relevant morphological variability in Plantago lanceolata L. Theoretical and Applied Genetics 73 (6): 903-914.

Wolkovich, E. M., Cook, B. I., Allen, J. M., Crimmins, T. M., Betancourt, J. L., Travers, S. E., Pau, S., Regetz, J., Davies, T. J., Kraft, N. J., Ault, T. R., Bolmgren, K., Mazer, S. J., McCabe, G. J., McGill, B. J., Parmesan, C., Salamin, N., Schwartz, M. D., Cleland, E. E. 2012: Warming experiments underpredict plant phenological responses to climate change. Nature 485 (7399): 494-497. doi: 10.1038/nature11014. 


\section{Appendix}

Table 4: Locations and characteristics of sample points.

Tabela 4: Lokacije in značilnosti posameznih vzorčnih točk.

\begin{tabular}{|c|c|c|c|c|c|c|c|c|}
\hline \multirow[t]{2}{*}{$\begin{array}{l}\text { Point } \\
\text { number }\end{array}$} & \multirow[t]{2}{*}{$\begin{array}{l}\text { Sample } \\
\text { origin }\end{array}$} & \multirow[t]{2}{*}{$\begin{array}{c}\text { Year of } \\
\text { sampling }\end{array}$} & \multicolumn{2}{|c|}{ Sample sites coordinates } & \multicolumn{2}{|c|}{$\begin{array}{l}\text { Meteorological stations } \\
\text { coordinates }\end{array}$} & \multicolumn{2}{|c|}{ Individuals scores } \\
\hline & & & $\mathrm{N}$ & $\mathrm{E}$ & $\mathrm{N}$ & E & $\mathrm{PC} 1$ & $\mathrm{PC} 2$ \\
\hline 1 & $\mathrm{KW}$ & 1905 & 50.39991 & 30.520236 & 50.44009 & 30.51724 & 0.093556 & -0.6143 \\
\hline 2 & $\mathrm{KW}$ & 1906 & 50.547158 & 30.219451 & 50.44009 & 30.51724 & 0.081959 & -0.2885 \\
\hline 3 & $\mathrm{KW}$ & 1909 & 50.444796 & 30.394016 & 50.44009 & 30.51724 & 0.622422 & -0.86202 \\
\hline 4 & $\mathrm{KW}$ & 1919 & 50.462556 & 30.586736 & 50.44009 & 30.51724 & 0.758972 & -0.41599 \\
\hline 5 & $\mathrm{KW}$ & 1921 & 50.239619 & 30.544557 & 50.44009 & 30.51724 & 0.510479 & 0.509591 \\
\hline 6 & $\mathrm{KW}$ & 1923 & 50.543594 & 30.570947 & 50.44009 & 30.51724 & 0.23704 & 0.913056 \\
\hline 7 & $\mathrm{KW}$ & 1923 & 50.440501 & 30.489486 & 50.44009 & 30.51724 & -0.25673 & 3.214668 \\
\hline 8 & $\mathrm{KW}$ & 1923 & 49.811897 & 30.064786 & 50.44009 & 30.51724 & -0.2905 & 0.425083 \\
\hline 9 & $\mathrm{KW}$ & 1923 & 49.79238 & 30.048244 & 50.44009 & 30.51724 & 1.547322 & -1.47832 \\
\hline 10 & $\mathrm{KW}$ & 1923 & 49.75861 & 30.20389 & 49.80262 & 30.12722 & 0.530997 & 0.256403 \\
\hline 11 & KW & 1924 & 50.477675 & 30.466582 & 50.44009 & 30.51724 & 0.246895 & 0.411293 \\
\hline 12 & KW & 1925 & 50.470588 & 30.280891 & 50.44009 & 30.51724 & 1.084344 & -1.01111 \\
\hline 13 & $\mathrm{KW}$ & 1929 & 49.481683 & 30.672704 & 50.44009 & 30.51724 & -0.89051 & -1.12925 \\
\hline 14 & KW & 1936 & 49.568337 & 30.72347 & 49.80262 & 30.12722 & -0.04521 & 0.841524 \\
\hline 15 & $\mathrm{KW}$ & 1940 & 50.221905 & 30.901316 & 50.34203 & 30.9512 & -0.24971 & 0.816348 \\
\hline 16 & $\mathrm{KW}$ & 1944 & 50.36647 & 30.590762 & 50.44009 & 30.51724 & 0.577278 & 0.912035 \\
\hline 17 & KW & 1946 & 50.290744 & 30.701893 & 50.44009 & 30.51724 & 1.814215 & -0.48636 \\
\hline 18 & $\mathrm{KW}$ & 1951 & 50.973432 & 30.146637 & 51.27574 & 30.2206 & 0.270447 & 0.668652 \\
\hline 19 & $\mathrm{KW}$ & 1983 & 50.502449 & 30.590057 & 50.44009 & 30.51724 & 1.0001 & 0.538829 \\
\hline 20 & $\mathrm{KW}$ & 1991 & 50.47043 & 30.523069 & 50.44009 & 30.51724 & -0.32269 & -1.06674 \\
\hline 21 & $\mathrm{KW}$ & 1991 & 50.451682 & 30.52317 & 50.44009 & 30.51724 & -0.08702 & 1.702424 \\
\hline 22 & $\mathrm{KW}$ & 1993 & 50.36647 & 30.590762 & 50.44009 & 30.51724 & 0.801485 & -1.3113 \\
\hline 23 & $\mathrm{KW}$ & 2005 & 50.401976 & 30.558586 & 50.44009 & 30.51724 & 1.228484 & -1.00163 \\
\hline 24 & $\mathrm{KW}$ & 2008 & 50.305881 & 30.288628 & 50.44009 & 30.51724 & -0.3379 & 0.936381 \\
\hline 25 & Field & 2015 & 49.658062 & 30.614577 & 50.44009 & 30.51724 & 0.270004 & 0.103414 \\
\hline 26 & Field & 2015 & 49.651995 & 30.595061 & 50.44009 & 30.51724 & 0.937855 & 0.598687 \\
\hline 27 & Field & 2015 & 49.651189 & 30.591542 & 50.44009 & 30.51724 & 0.774936 & -0.16035 \\
\hline 28 & Field & 2015 & 49.651190 & 30.591543 & 50.44009 & 30.51724 & 0.824385 & -0.27094 \\
\hline 29 & Field & 2019 & 50.458611 & 30.3925 & 50.44009 & 30.51724 & -1.80772 & -0.52292 \\
\hline 30 & Field & 2019 & 50.527222 & 30.259444 & 50.44009 & 30.51724 & -2.27714 & 0.742828 \\
\hline 31 & Field & 2019 & 50.474722 & 30.450833 & 50.44009 & 30.51724 & -1.44896 & -0.79019 \\
\hline 32 & Field & 2019 & 50.395000 & 30.616944 & 50.44009 & 30.51724 & -1.92485 & -1.15452 \\
\hline 33 & Field & 2019 & 50.3925 & 30.597778 & 50.44009 & 30.51724 & -1.15147 & 0.68061 \\
\hline 34 & Field & 2019 & 50.401944 & 30.558333 & 50.44009 & 30.51724 & -2.03656 & -1.59912 \\
\hline 35 & Field & 2019 & 50.454167 & 30.601944 & 50.44009 & 30.51724 & -0.82106 & -0.83005 \\
\hline 36 & Field & 2019 & 50.389444 & 30.504444 & 50.44009 & 30.51724 & -0.26515 & 0.721769 \\
\hline
\end{tabular}


Table 5: A correlation matrix for the meteorological parameters.

Tabela 5: Korelacijska matrika meteoroloških podatkov.

\begin{tabular}{|c|c|c|c|c|c|c|c|c|c|c|c|c|}
\hline & $\mathrm{Tm}$ & $\mathrm{Hm}$ & $\mathrm{Pm}$ & Tan & Han & Pan & Tsp & Hsp & Psp & Tan-1 & Pan-1 & Tss- 1 \\
\hline $\mathrm{Hm}$ & -0.17 & & & & & & & & & & & \\
\hline $\mathrm{Pm}$ & 0.45 & 0.29 & & & & & & & & & & \\
\hline Tan & -0.33 & -0.20 & -0.07 & & & & & & & & & \\
\hline Han & 0.21 & 0.64 & 0.09 & -0.41 & & & & & & & & \\
\hline Pan & -0.12 & 0.5 & 0.28 & 0.03 & 0.58 & & & & & & & \\
\hline Tsp & 0.21 & -0.23 & 0.28 & 0.69 & -0.17 & 0.30 & & & & & & \\
\hline Hsp & -0.27 & 0.61 & -0.21 & -0.63 & 0.77 & 0.22 & -0.60 & & & & & \\
\hline Psp & 0.18 & 0.22 & 0.34 & -0.12 & 0.16 & 0.34 & -0.18 & 0.09 & & & & \\
\hline Tan-1 & 0.41 & -0.36 & 0.26 & 0.32 & -0.23 & -0.26 & 0.27 & -0.49 & 0.18 & & & \\
\hline Pan-1 & 0.27 & -0.31 & 0.17 & 0.62 & -0.05 & 0.27 & 0.65 & -0.49 & -0.02 & 0.58 & & \\
\hline Tss-1 & 0.64 & -0.09 & 0.44 & 0.40 & -0.07 & -0.06 & 0.48 & -0.50 & 0.07 & 0.59 & 0.39 & \\
\hline Pss-1 & 0.42 & -0.16 & 0.22 & 0.39 & 0.15 & 0.36 & 0.48 & -0.32 & 0.12 & 0.55 & 0.91 & 0.49 \\
\hline
\end{tabular}

Note: pink indicates statistically significant positive, green - negative correlations

Table 6: A correlation matrix for the morphological parameters.

Tabela 6: Korelacijska matrika morfoloških spremeljivk.

\begin{tabular}{lrrrrrrr} 
& \multicolumn{1}{c}{$\mathrm{L}$} & $\mathrm{W}$ & $\mathrm{Li}$ & $\mathrm{Lg}$ & $\mathrm{LWr}$ & $\mathrm{S}$ & $\mathrm{LP}$ \\
$\mathrm{W}$ & 0.63 & & & & & & \\
$\mathrm{Li}$ & 0.47 & 0.37 & & & & & \\
$\mathrm{Lg}$ & 0.61 & 0.46 & 0.51 & & & & \\
$\mathrm{LWr}$ & 0.61 & -0.19 & 0.14 & 0.24 & & & \\
$\mathrm{~S}$ & 0.80 & 0.87 & 0.47 & 0.45 & 0.11 & & \\
$\mathrm{LP}$ & 0.82 & 0.39 & 0.53 & 0.67 & 0.58 & 0.59 & \\
S/LP & 0.07 & 0.67 & -0.01 & -0.03 & -0.52 & 0.52 & -0.30 \\
\hline
\end{tabular}

Note: marks are similar to ones in Table 5

Table 7: A correlation matrix for the morphological and climatic parameters.

Tabela 7: Korelacijska matrika morfoloških in klimatskih spremeljivk.

\begin{tabular}{lrrrrrrrr} 
& L & W & \multicolumn{1}{c}{ Li } & \multicolumn{1}{c}{ Lg } & LWr & \multicolumn{1}{c}{ S } & \multicolumn{1}{c}{ LP } & \multicolumn{1}{c}{ Slp } \\
Tm & 0.66 & 0.33 & 0.48 & 0.39 & 0.44 & 0.58 & 0.54 & 0.11 \\
Hm & -0.08 & 0.00 & -0.28 & -0.19 & 0.00 & -0.18 & -0.28 & 0.13 \\
Pm & 0.44 & 0.02 & 0.12 & 0.19 & 0.51 & 0.26 & 0.35 & -0.10 \\
Tan & -0.43 & -0.09 & 0.17 & -0.05 & -0.36 & -0.09 & -0.08 & -0.01 \\
Han & 0.41 & 0.34 & -0.05 & -0.02 & 0.14 & 0.35 & 0.04 & 0.24 \\
Pan & 0.21 & 0.08 & -0.29 & -0.06 & 0.26 & 0.09 & -0.03 & 0.04 \\
Tsp & 0.08 & 0.10 & 0.26 & 0.19 & -0.02 & 0.26 & 0.13 & 0.13 \\
Hsp & -0.04 & 0.14 & -0.27 & -0.13 & -0.08 & -0.12 & -0.26 & 0.22 \\
Psp & 0.28 & 0.12 & -0.01 & 0.03 & 0.22 & 0.19 & 0.13 & 0.11 \\
Tan-1 & 0.39 & 0.28 & 0.52 & 0.16 & 0.13 & 0.48 & 0.46 & 0.04 \\
Pan-1 & 0.44 & 0.34 & 0.45 & 0.30 & 0.19 & 0.54 & 0.51 & 0.05 \\
Tss-1 & 0.37 & 0.25 & 0.42 & 0.24 & 0.14 & 0.39 & 0.36 & 0.03 \\
Pss-1 & 0.60 & 0.45 & 0.47 & 0.31 & 0.29 & 0.63 & 0.58 & 0.08 \\
\hline
\end{tabular}

